Erni Wahyuningsih

Syindi Oktaviani Tolinggi ${ }^{*}$

R. Umi Baroroh

Universitas Islam Negeri Sunan

Kalijaga, Yogyakarta

${ }^{*}$ Corresponding author email: syindioktaviani0410@gmail.com

\section{Pendekatan Humanistik Melalui Permainan Edukatif Bahasa dalam Pembelajaran Bahasa Arab di Sekolah Islam Terpadu}

\author{
DOI: $10.18196 /$ mht.v4i1.12437
}

\begin{abstract}
There are four language skills (مبارةاللغة) in learning Arabic that ought to be mastered in order to obtain an appropriate Arabic learning process. To achieve this, an approach is needed, one of which is a humanistic approach. The humanistic approach through language educational games will give a pleasant impression so that students can follow the Arabic learning process as expected. This study aims to examine the humanistic approach in learning Arabic through language educational games at the Integrated Islamic School which can later be used as a reference for schools to create creative and innovative learning processes. This research uses a research method, namely library research. The number data are primary data and secondary data in the form of books, journal articles and others related to the humanistic approach in learning Arabic through language educational games at the Integrated Islamic School. An integrated Islamic school is a school that has a full day learning system so that by using a humanistic approach through language educational games, students can actualize themselves in learning Arabic more fun and not feel bored.
\end{abstract}

Keywords: Humanistic Approach; Language Educational Games; Integrated Islamic School

\title{
ABSTRAK
}

Ada empat keterampilan berbahasa (معارة/اللغة) dalam pembelajaran bahasa Arab yang wajib dikuasai agar tercapai proses pembelajaran bahasa Arab yang sesuai. Untuk mencapai hal tersebut, dibutuhkan beberapa pendekatan salah satunya adalah pendekatan humanistik. Pendekatan humanistik melalui permainan edukatif bahasa akan memberikan kesan yang menyenangkan sehingga siswa bisa mengikuti proses pembelajaran bahasa Arab dengan hasil yang diharapkan. Penelitian ini bertujuan untuk mengkaji tentang pendekatan humanistik dalam pembelajaran bahasa Arab melalui permainan edukatif bahasa di Sekolah Islam Terpadu yang nantinya dapat dijadikan acuan bagi sekolah-sekolah untuk menciptakan proses pembelajaran yang kreatif dan inovatif. Penelitian ini menggunakan metode penelitian yakni kepustakaan (library research). Adapun sumber datanya adalah data primer dan data sekunder yang berupa buku-buku, artikel jurnal, dan lainnya terkait pendekatan humanistik dalam pembelajaran bahasa Arab melalui permainan edukatif 
bahasa di Sekolah Islam Terpadu. Sekolah Islam Terpadu merupakan sekolah yang memiliki sistem belajar secara full day sehingga dengan menggunakan pendekatan humanistik melalui permainan edukatif bahasa, peserta didik dapat mengaktualisasikan dirinya dalam pembelajaran bahasa Arab dengan lebih menyenangkan dan tidak merasa bosan.

Kata Kunci: Pendekatan Humanistik; Permainan Edukatif Bahasa; Sekolah Islam Terpadu $==$ = = = = = = = = = = = = = = = = = = = = = = = = = = = = = = = =

\section{PENDAHULUAN}

Pendidikan adalah salah satu aspek berarti untuk kehidupan manusia. Pendidikan ialah kegiatan yang terprogram guna mempengaruhi dan membantu seseorang yang bertujuan untuk tingkatkan ilmu pengetahuan, jasmani serta akhlak sehingga lambat laun dapat mengantarkannya kepada cita-cita dan tujuan tertinggi. Adapun dalam upaya untuk mencapai tujuan pendidikan, pendidikan memerlukan proses yang disebut dengan pembelajaran (Trahati 2015, 11). Pembelajaran merupakan proses memperoleh pengetahuan juga keterampilan. Memperoleh pengetahuan dan keterampilan tersebut dapat dilakukan dengan proses belajar.

Belajar didefinisikan sebagai modifikasi atau penguatan perilaku melalui pengalaman (learning is defined as the modification or strengthening of behavior through experience). Belajar adalah sesuatu proses atau sesuatu aktivitas kegiatan tidaklah sesuatu hasil ataupun tujuan. Belajar bukan sekedar mengingat melainkan jauh daripada itu, yakni mengalami/merasakan. Ada pula hasil belajar adalah bukan sesuatu penguasaan hasil latihan akan tetapi perubahan perilaku, kelakuan atau tingkah laku (Husamah 2018, 4). Hilmi mengatakan bahwa belajar adalah kegiatan penting dalam upaya untuk mencapai tujuan pendidikan (Hilmi 2012, 1). Menurut pandangan Sanusi, proses kegiatan pembelajaran adalah suatu kegiatan yang dilaksanakan oleh pendidik dalam mentransfer ilmu atau penyampaian materi yang diberikan kepada peserta didik pada suatu lembaga pendidikan tertentu yang bertujuan untuk memberikan pengaruh/cara bagi peserta didik guna pencapaian tujuan pendidikan yang telah ditetapkan tersebut (Sanusi 2013, 123).

Suatu pendekatan dalam pembelajaran sangat dibutuhkan guna memunculkan ketertarikan atau bahkan minat peserta didik dalam hal melaksanakan proses pembelajaran tersebut, termasuk dalam kegiatan pembelajaran bahasa. Bahasa dan manusia merupakan kebutuhan yang saling terkait satu sama lain. Hal ini dikarenakan bahasa adalah alat/perlengkapan yang digunakan untuk berpikir 
manusia. Oleh sebab itu, arti yang tercakup dalam kaidah kebahasaan hendak mengekstraksi nilai-nilai humanistik selaku wujud dari semangat dalam mengkontekstualisasikan bahasa tersebut (Aziz 2019, 299-300). Bahasa digunakan oleh masyarakat untuk alat komunikasi sebagai wujud keterikatan dengan antar anggota masyarakat. Tidak terdapat yang namanya masyarakat tanpa bahasa serta tidak terdapat bahasa tanpa masyarakat (Soeparno 2002, 5), hal ini berkaitan dengan bahasa Arab.

Keberadaan bahasa Arab dengan agama Islam memiliki keterikatan, hal ini menjadikan bahasa Arab sebagai aspek penting yang harus dipelajari oleh masyarakat, khususnya umat muslim. Islam dan bahasa Arab merupakan dua hal yang tidak dapat dipisahkan. Hal ini dikarenakan Al-Qur'an dan Al-Hadist menghimpun pada semua ajaran Islam, yang mana kedua sumber ajaran agama Islam tersebut berkaitan dengan aspek bahasa Arab. agar Islam dapat dipahami dan dikaji dengan sempurna maka Al-Qur'an dan Al-Hadist menjadi salah satu aspek yang utama untuk dipelajari. Namun, untuk mempelajari Al-Qur'an dan Al-Hadist, maka dibutuhkan keterampilan berbahasa Arab yang mumpuni (Ma'ruf 2009, 7).

Mujib mengatakan mempelajari bahasa adalah suatu pekerjaan yang panjang serta kompleks, kemudian juga bukanlah serangkaian langkah praktis yang mampu diamati atau diprogram pada sebuah pedoman ringkas (Mujib 2011, 5). Oleh karenanya, masih banyak muncul problem dalam pembelajaran bahasa Arab. Problem tersebut dapat terjadi dikarenakan oleh berbagai faktor, seperti peserta didik kurang siap dalam mengikuti kegiatan pembelajaran bahasa Arab, materi bahasa Arab begitu bersifat kompleksitas, hal ini menjadikan taraf kesulitan tinggi di teknik, strategi, serta metode penyampaiannya, guru yang mengajar bersifat monoton dan hanya berfokus pada satu sumber belajar sehingga menjadikan tujuan pengajaran tidak tercapai dengan maksimal serta kurangnya pemanfaatan sarana dan prasarana.

Pembelajaran bahasa Arab seharusnya dapat memicu minat para peserta didik sehingga tercapainya hasil pembelajaran yang sesuai harapan. Oleh karena itu, berbagai pendekatan diperlukan agar peserta didik lebih mengetahui dan menguasai suatu bahasa Arab. Tadjuddin, dalam penelitiannya mengatakan tentang pendekatan pembelajaran untuk menciptakan pembelajaran bahasa yang efektif yakni 
pendekatan humanistik, menurutnya berdasarkan pendekatan humanistik ini akan terlihat bahwa keaktifan dari pembelajarnya dibutuhkan dalam kegiatan belajar mengajar bahasa Arab, bukan hanya keaktifan dari pendidik. Dalam hal ini, pembelajar dituntut untuk lebih aktif dalam memahami bahasa Arab sedangkan pendidik juga turut serta dalam proses kegiatan belajar mengajar hanya saja ia cenderung berfungsi sebagai motivator, administrator, dinamisator, evaluator dan lain sebagainya. Kemudian pendidik juga harus mengetahui potensi-potensi yang dimiliki oleh seorang pembelajar (Tadjuddin 2017, 33).

Dalam penelitiannya, Maimunah berpendapat bahwa konsep humanistik ini mengacu tentang mengajarkan manusia dengan mempunyai rasa kemanusiaan yang yang mendalam sebagai contoh menghilangkan sifat bertindak semaunya, egois, otoriter dan individualis, tidak berbicara sesuka hati pada orang yang diajak bicara, serta mempunyai sikap toleransi dan saling memahami (Maimunah 2016, 77).

Dalam menentukan suatu pendekatan pembelajaran bahasa Arab diperlukan adanya beberapa hal yang menjadi perhatian. Salah satu hal penting yang menjadi perhatian tentunya adalah peserta didik. Agar pembelajaran bisa bermakna untuk para peserta didik, maka dibutuhkan suatu pendekatan yang dapat menempatkan peserta didik sebagai subjek. Tentunya dalam hal ini, teori humanistik memiliki peran. Selain, pendidik disini juga memiliki peran dalam pembelajaran dengan pendekatan humanistik yaitu sebagai fasilitator sedangkan peserta didik sebagai pelaku utama (student center).

Baroroh, mengatakan dalam penelitiannya mengenai metode hypnoteaching, belajar bahasa Arab dengan metode hypnoteaching ini dilakukan dengan selalu menginisiasi pembelajaran melalui pemberian motivasi, menyamaratakan gerak tubuh, posisi, bahasa, dan gelombang otak antara para peserta didik. Metode hypnoteaching ini bahwa pendidik harus menggunakan kata-kata positif. Selain itu pendidik juga mencairkan suasana belajar dengan memainkan permainan edukatif seperti sulap, menebak kata dan lain-lain sehingga peserta didik akan fokus dalam belajar dan suasana menjadi menyenangkan (Baroroh 2019, 145).

Dalam penelitian Nasrulloh dkk, ditemukan bahwa di proses pembelajaran bahasa Arab dengan memakai permainan edukatif pada siswa sehingga pada permainan bahasa mempunyai tujuan ganda, yaitu memperoleh kegembiraan serta 
digunakan untuk melatih keterampilan berbahasa eksklusif. dalam penerapan permainan pada pelajaran bahasa Arab, siswa pada tuntut buat menonjolkan keterampilan berbicara bahasa Arab sehingga dengan permainan ini siswa bisa mendapatkan hal yang baru, yang belum pernah didapatkan di kelas sebelumnya. Pembelajaran bahasa Arab dengan menggunakan permainan serta lagu-lagu berbahasa Arab menerima respons positif yang maksimal berasal dari siswa (Nasrulloh dkk 2020, 8).

Dalam penelitian yang lain, yang dilakukan oleh Uliyah dkk, permainan edukatif pembelajaran bahasa Arab adalah suatu metode pembelajaran yang di mana akan menyampaikan rangsangan kepada siswa dan tidak pribadi sifat ketidaksukaannya terhadap pelajaran bahasa Arab akan sedikit berangsur sebagai suka seiring menggunakan pembelajaran yang dilakukan secara menyenangkan. karenanya, saat siswa terlibat dalam permainan secara berfokus sifat sukarela serta motivasi datang berasal dalam diri peserta didik sendiri secara spontan (Uliyah 2019, 35-36).

Arifin mengatakan, adanya permainan bahasa yang dilaksanakan yaitu guru di dalam kelas, tentu akan mengubah kondisi kelas yang lebih baik. Psikologi peserta didik yang mungkin sedang stres atau bosan karena belajar yang kaku akan mendapatkan kesadaran. serta sifat cuek peserta didik kepada pelajaran lambat laun akan terkikis seiring dilaksanakannya permainan bahasa. Melalui bermain, siswa bisa menstimulasi inderanya, mengkoordinasikan penglihatan menggunakan gerakan, menaikkan kemampuan tubuhnya, mendapatkan keterampilan baru, mengatasi perasaan yang tidak nyaman, mengalami kegembiraan dalam beraktivitas, dan menjadikannya senang dalam belajar bahasa Arab (Arifin 2017, 305).

Adapun pada penelitian Latuconsina, yaitu penggunaan bentuk-bentuk permainan dalam pembelajaran dapat memberikan iklim yang menyenangkan pada proses belajar. sebagai akibatnya proses pembelajaran dapat dilakukan menggunakan kalem tanpa adanya keterpaksaan. menggunakan cara yang mudah, sel-sel otak mereka bisa berkembang. Selanjutnya mereka bisa menyerap gosip serta memperoleh kesan yang mendalam terhadap materi serta bisa disimpan terus pada ingatan jangka panjang (Latuconsina 2018, 147). 
Dengan demikian permainan edukatif bahasa dalam pembelajaran bahasa Arab sangat diperlukan untuk menunjang pembelajaran. Sehingga aspek pendekatan humanistik melalui permainan edukatif bahasa memiliki peran penting dalam pelaksanaan tujuan pendidikan Sekolah Islam Terpadu terutama dalam kegiatan belajar mengajar bahasa Arab.

Pembelajaran bahasa Arab sendiri sudah sekian lamanya menjadi salah satu pelajaran yang terdapat pada kurikulum sekolah di Indonesia. Terutama pada sekolah berbasis Islam seperti Pesantren, Madrasah, Sekolah (awam) dan lain-lain. pada awal abad ke-21 hanya ada tiga contoh forum pendidik yaitu pesantren, madrasah dan sekolah (awam). Seiring berkembangnya zaman, sekolah Islam Terpadu mulai bermunculan yakni mulai tingkat Taman Kanak-kanak (TK) sampai Sekolah Menengah Atas (Sekolah Menengan Atas). Menurut Hisyam, sampai saat ini terdapat sekitar 1.000 Sekolah Islam Terpadu yang tergabung dalam Jaringan Sekolah Islam Terpadu (JSIT) yang kepengurusannya telah beredar sampai penjuru di seluruh negara Indonesia serta ada kurang lebih 10.000 Sekolah Islam Terpadu yang belum atau secara struktural tidak bergabung dalam JSIT (Mualimin 2017, 101)

Sekolah Islam Terpadu merupakan sekolah yang berlandaskan Al-Qur'an dan As-Sunnah dengan mengedepankan implementasi konsep pendidikan Islam. Dalam aplikasinya ini, sekolah Islam terpadu juga dapat diartikan sebagai sekolah yang penerapannya yakni memadukan pendidikan umum dengan pendidikan agama yang dijalin dengan seperangkat kurikulum. Penekanan keterpaduan pada metode pembelajaran di sekolah Islam terpadu juga diperhatikan sehingga bisa mengoptimalkan ranah kognitif, afektif dan psikomotorik. Selain itu juga, perpaduan pendidikan aqliyah, pendidikan ruhiyah maupun pendidikan jasadiyah terangkum dalam Sekolah Islam Terpadu. Sekolah, keluarga dan masyarakat juga ikut terlibat dan menjadi partisipasi aktif dalam lingkungan belajar di Sekolah Islam Terpadu.

Fokus permasalahan pada artikel ini mengenai pendekatan humanistik melalui permainan edukatif bahasa dalam kegiatan belajar mengajar bahasa Arab yang terjadi di Sekolah Islam Terpadu. Kurnaengsih, mengemukakan tentang Sekolah Islam Terpadu memberikan penekanan terhadap penanaman mata pelajaran keagamaan seperti teologi (akidah), moral (akhlaq) dan ibadah praktis. Ia juga mengatakan yang tercantum dalam teori pendidikan al-Banna, Sekolah Islam 
Terpadu bertujuan untuk menciptakan moralitas dan membangun karakter peserta didik dengan menggunakan warna Islam yang ditinjau tentunya dalam pola berpikir, sikap, dan praktik dalam kehidupan sehari-hari. Tujuan dalam pendidikan ini tak hanya sekedar menanamkan pengetahuan, baik pada ilmu kepercayaan juga awam melainkan pendidikan ini dijadikan sebagai cara membentuk pribadi Muslim yang utuh, baik asal segi berpikirnya juga berperilaku (Kurnaengsih 2015, 83).

Oleh karena itu, sebagaimana sistem pendidikan di sekolah Islam terpadu yang dijelaskan di atas, diharapkan peserta didik juga dapat terfasilitasi dalam mempelajari bahasa Arab dengan sangat baik. Peserta didik dapat merasakan kenyamanan melalui proses belajar mengajar bahasa Arab yang mengasyikkan bagi mereka dengan adanya permainan edukatif bahasa berdasarkan pendekatan humanistik. Dengan waktu belajar yang full day school maka dengan adanya pembelajaran yang having fun bagi peserta didik, maka mereka tidak akan merasakan kebosanan dan kejenuhan.

Jika mengingat betapa pentingnya mempelajari bahasa Arab, bahkan semakin berkembangnya zaman, tujuan mempelajari bahasa Arab tidak hanya sebatas untuk keperluan agama saja, melainkan lebih luas lagi seperti untuk keperluan pendidikan, perjalanan, pariwisata, ekonomi, politik dan berbagai kebutuhan peserta didik di kehidupan pada masa depan. Penulis berharap nantinya artikel ini bisa dijadikan sebagai acuan untuk Sekolah Islam Terpadu maupun sekolah-sekolah lainnya dalam penggunaan pendekatan humanistik menggunakan permainan edukatif bahasa dalam kegiatan belajar mengajar bahasa Arab yang memfokuskan peserta didik agar turut aktif dalam proses pembelajaran.

\section{METODE PENELITIAN}

Penulis menggunakan metode penelitian dengan jenis penelitian kepustakaan (library research). Sumber informasi atau sumber data terdapat dua jenis yakni sumber data primer dan juga sumber data sekunder.

Sumber data primer adalah buku Belajar dan Pembelajaran karya dari Husamah Dkk buku Mazhab Ketiga Psikologi Humanistik Abraham Maslow (Terjemahan), serta buku Fathul Mujib dan Nailur Rahmawati dengan judul bukunya Metode Permainan-Permainan Edukatif dalam Belajar Bahasa Arab. Sedangkan 
sumber data/informasi sekunder meliputi buku dan artikel-artikel jurnal terkait yang membahas tentang pendekatan humanistik, permainan edukatif bahasa, pembelajaran bahasa Arab berbasis humanistik, Sekolah Islam Terpadu dan pembelajaran bahasa Arab di sekolah Islam Terpadu serta lain sebagainya.

Penulis menggunakan teknik pengumpulan data berupa pencarian buku-buku, artikel jurnal atau apapun yang terkait dengan pendekatan humanistik dalam kegiatan belajar mengajar bahasa Arab. Kemudian setelah bahan-bahan tersebut terkumpul, penulis menyajikannya dengan menggunakan teknik analisis data deskriptif. Penulis mendeskripsikan data yang telah terkumpul kemudian menganalisanya dengan cara content analyzing atau menganalisis isinya yang memiliki kaitan dengan pendekatan humanistik yang menggunakan permainan edukatif bahasa pada pembelajaran bahasa Arab di Sekolah Islam Terpadu.

\section{LANDASAN TEORI}

\section{Pendekatan Humanistik}

Secara etimologis humanistik asal katanya dari kata latin yakni humanus dan memiliki akar katanya yaitu homo yang berarti manusia (Maksudin 2018, 179). Menurut Desmita dalam tulisan Solichin, pada pertengahan abad ke 20 muncul teori humanistik sebagai wujud adanya reaksi pada teori behavioristik dan psikodinamik (Solichin 2018, 4).

Humanistik didefinisikan yakni sebagai orientasi teoritis yaitu memberikan penekanan terhadap suatu kualitas seorang manusia yang unik, dalam hal ini berkaitan dengan free will (kemampuan bebas) dan juga mempunyai potensi yang dimiliki untuk mengembangkan dirinya (Rachmahana 2008, 114). Waddock, mengatakan dalam penelitiannya bahwasanya dalam kepemimpinan keterampilan yang harus ada adalah keterampilan fungsional, teknis dan analitis. Namun pendekatan humanistik disini juga lebih ditekankan untuk memimpin dan mengelola individu yang telah maju dalam pekerjaan mereka ke jenis posisi di mana kemampuan humanistik terkait dengan kebijaksanaan imajinasi moral, pemahaman sistem, dan kepekaan estetika dalam layanan tentang kebaikan yang lebih besar sangat penting dan dapat dipelajari dengan lebih baik (Waddock 2016, 58). 
Teori pendekatan humanistik yang biasa juga disebut sebagai teori belajar humanistik adalah suatu teori pada kegiatan belajar mengajar pembelajaran yang memfokuskan untuk bagaimana cara memanusiakan manusia dan juga peserta didik memiliki kemampuan untuk mengembangkan potensi yang dimilikinya. Dierksmeier, mengatakan tentang humanistik dalam lingkupan ekonomi yang dikenal dengan manajemen humanistik, ia mengatakan bahwa manajemen humanistik ini tidak hanya membela hak asasi masing-masing manusia tetapi juga juga mengingatkan kita akan tanggung jawab manusiawi kita masing-masing (Dierksmeier 2016, 28).

Ada tiga tokoh pada teori humanistik, yaitu Carl Roger, Abraham Maslow dan Arthur Comb. Ada juga tokoh lain yaitu Kolb, Honey dan Mumford, Habermas, Bloom dan Krathwol (Husamah 2018, 120-158).

Carl R. Rogers merupakan seorang pakar psikologi humanistik yang mempunyai gagasan-gagasan yang berpengaruh pada pikiran dan praktek psikologi terhadap semua bidang, bidang tersebut diantaranya yakni klinis, pendidikan, dan lain sebagainya. Adapun fokus Rogers terhadap bidang pendidikan, ia menyatakan tentang prinsip-prinsip belajar yakni humanistik. Prinsip tersebut meliputi hasrat untuk terus belajar, belajar yang mempunyai arti, belajar tanpa tekanan bahkan ancaman, belajar sesuai kemauan diri pribadi sendiri, dan juga belajar dan perubahan (Rachmahana 2008, 101-103).

Berikut penjelasan tentang prinsip-prinsip tersebut adalah:

a. Hasrat untuk terus Belajar

Menurut Rogers, pada hakikatnya manusia memiliki rasa ingin tahu yang tinggi artinya hasrat untuk terus belajar tentang hal apapun itu selalu ada (Rachmahana 2008, 101-103). Rasa ingin tahu dan mempelajari hal tertentu ini merupakan pendapat atau asumsi dasar pada pendidikan humanistik. Misalnya di dalam suatu kelas, peserta didik didorong untuk ingin tahu, untuk mengetahui minatnya dan untuk mencari apa yang penting bagi dirinya dan berarti tentang lingkungan di sekitarnya.

b. Belajar yang mempunyai Arti

Belajar akan mempunyai arti atau bahkan akan memiliki makna jika ia mempelajari sesuatu dengan kebutuhannya. Artinya, anak/peserta didik akan 
mudah memahami dan cepat tangkap jika yang ia pelajari tersebut memiliki arti baginya.

\section{c. Belajar Tanpa Tekanan Bahkan Ancaman}

Peserta didik memiliki kebebasan untuk mencoba pengalaman-pengalaman baru tanpa ada yang tersinggung atau menyinggung perasaan pihak manapun. Proses belajar peserta didik tersebut akan berjalan sesuai harapan dan peserta didik dapat menguji kemampuannya pula. Peserta didik terbebas dari tekanan bahkan ancaman.

d. Belajar sesuai Kemauan Diri Sendiri

Proses belajar akan melibatkan perasaan dan pikiran si pembelajarnya, maka dari itu belajar haruslah dilaksanakan atas kehendak dan kemauan pribadi diri sendiri. Peserta didik dapat memilih arah belajarnya sendiri sehingga akan memberikan motivasi kepadanya untuk "belajar bagaimana caranya belajar" (to learn how to learn). Memang, tidak dapat dipungkiri bahwa menguasai suatu pelajaran penting, namun akan lebih penting jika pembelajar mampu mendapatkan keterampilan untuk mencari sumber, merumuskan masalah, menguji hipotesis atau asumsi serta menilai hasil. Belajar dengan kemauan sendiri akan dapat memusatkan perhatian peserta didik terhadap proses bahkan hasil belajar peserta didik tersebut.

e. Belajar dan Perubahan

Proses belajar di sini sangat diperuntukkan, hal ini dikarenakan proses belajar yang akan membawa perubahan di masa depan. Menurut Rogers, apa yang dipelajari saat ini tidak akan cukup untuk kebutuhan di masa depan. Namun, yang dibutuhkan saat ini adalah peserta didik atau seseorang yang dapat membekali dirinya untuk hidup di masa kini dan masa yang akan datang. Karena tidak menutup kemungkinan zaman akan terus berubah. Ilmu pengetahuan dan teknologi akan mengalami perubahan seiring berjalannya waktu. Oleh sebab itu, yang terpenting saat ini adalah seseorang yang mampu belajar dimanapun ia berada, yang akan terus belajar di lingkungan yang penuh perubahan dan akan terus berubah. Seseorang yang dapat beradaptasi dengan berbagai perubahan lingkungannya. 
Carl Roger menjelaskan tentang belajar humanistik yang sesungguhnya tidak akan berlangsung jika tidak ada melibatkan intelektual maupun emosional (Rachmahana 2008, 101-103). Contohnya Andi adalah anak yang cerdas akan tetapi jika dia tidak ingin belajar maka dia tidak belajar -misalnya- belajar bahasa Indonesia, maka dia tidak belajar karena dia tidak ada semangat belajar. Namun dia memahami mata pelajaran tersebut.

Menurut Abraham Maslow, teori belajar humanistik merupakan proses untuk memahami tentang siapa diri kita sendiri, bagaimana kita menjadi diri kita sendiri, hingga potensi apa yang dimiliki diri kita untuk dapat kita kembangkan ke arah tertentu (Rachmahana 2008, 101-103). Contohnya seperti Raisya adalah siswi yang rajin. Dia tertarik dengan mata pelajaran seni budaya, salah satunya pada bidang keterampilan melukis. Tidak hanya tertarik, Raisya juga mengikuti komunitas melukis dan mengikuti berbagai perlombaan melukis. Sehingga, Raisya dapat mengembangkan potensi yang dimiliki pada dirinya sendiri.

Implikasi dari teori Maslow mempunyai peranan yang sangat penting terhadap dunia pendidikan. Misalnya pada kegiatan proses belajar mengajar, pendidik disarankan untuk memperhatikan teori ini. Di dalam kelas, pendidik menemukan masalah yang berkaitan dengan peserta didik seperti pendidik kesulitan untuk mengerti peserta didik yang tidak mengerjakan pekerjaan rumah, pendidik melihat ada peserta didik yang tidak tenang di ruang kelas atau bahkan tentang peserta didik yang tidak memiliki semangat untuk dirinya agar termotivasi pada proses pembelajaran. Maslow berpendapat, hal ini tidak sepenuhnya kesalahan peserta didik dan pendidik tidak dapat langsung menyalahkan peserta didik (Rachmahana 2008, 101-103). Kemungkinan yang terjadi misal peserta didik tidak terpenuhi kebutuhannya seperti belum atau tidak sarapan yang cukup, tidak dapat tidur dengan nyaman dan nyenyak atau ada masalah pribadi yakni keluarga , orang tua dan saudaranya sehingga peserta didik tersebut merasakan takut, khawatir, cemas dan lain sebagainya.

Sedangkan menurut Arthur Comb, teori belajar humanisme adalah belajar terjadi jika memiliki arti bagi pribadi individu (Rachmahana 2008, 101-103). Pendidik tidak dapat memberikan paksaan terhadap materi yang tidak diminati atau tidak sesuai dengan kehidupan mereka. Misalnya saja, peserta didik tidak memahami 
mata pelajaran matematika atau seni budaya bukan karena ia tak pandai melainkan karena peserta didik enggan bahkan ada yang sampai terpaksa. Mereka merasakan bahwa sebenarnya tidak ada alasan yang cukup penting untuk mereka harus mempelajarinya.

Teori belajar humanistik ini memiliki kelebihan maupun kekurangan. Kelebihannya adalah peserta didik merasa senang dalam belajar karena dengan kemauannya, pendidik menerima apa yang ada pada peserta didik dengan apa adanya dan mengerti pola pemikiran peserta didik, serta peserta didik dapat mempunyai pengalaman yang banyak untuk mengeksplorasi dirinya. Namun teori ini juga memiliki kekurangan yaitu bersifat individu, sulit diterapkan dalam praktik dan kebanyakan dari peserta didik sulit memahami dirinya dan potensi yang dimilikinya sehingga dapat menyebabkan ketertinggalan terhadap proses belajar (Muyassarah 2016, 425).

Kemudian untuk ciri-ciri pada teori belajar humanistik ini diantaranya adalah penekanan terhadap perkembangan positif, belajar akan dianggap berhasil apabila peserta didik dapat memahami lingkungan dan pribadi dirinya sendiri serta memandang bahwa belajar sebagai proses individu yang meliputi kognitif, afektif dan psikomotorik.

Qodir, dalam penelitiannya mengatakan bahwa terdapat beberapa model pembelajaran humanistik diantaranya adalah: (1) Humanizing of the classroom adalah suatu model pembelajaran dimana berpatokan pada tiga hal diantaranya kesadaran akan diri yang terus tumbuh dan berkembang serta selalu akan berubah, mengidentifikasi konsep dan karakteristik diri serta menyelaraskan pemahaman hati dan pikiran. (2) Active learning adalah strategi pendidikan yang lebih banyak mengaitkan peserta didik dalam mengakses bermacam data serta pengetahuan untuk dipahami serta dikaji dalam proses kegiatan belajar mengajar di kelas, sehingga mereka memperoleh bermacam pengalaman yang bisa tingkatkan kompetensinya. Tidak hanya itu, belajar aktif pula memperbolehkan peserta didik bisa meningkatkan keahlian analisis serta sintesis dan sanggup merumuskan nilainilai baru yang diperoleh dari hasil analisis peserta didik itu sendiri. (3) Quantum learning adalah metode pengubahan berbagai interaksi, ikatan serta inspirasi yang terdapat di dalam serta di sekitar kegiatan belajar. Dalam praktiknya, quantum 
learning mengemukakan pendapat bila peserta didik sanggup memakai kemampuan nalar serta emosinya secara teratur, mereka akan sanggup menciptakan kenaikan prestasi yang tidak dapat terduga tadinya dengan hasil memperoleh prestasi yang cemerlang. The accelerated learning adalah kegiatan belajar mengajar yang berlangsung secara kilat, mengasyikkan, serta memuaskan. Dalam model ini, pendidik diyakini sanggup mengelola kelas dengan pendekatan Somatic, Auditory, Visual, serta Intellectual ( Qodir 2017, 194).

Teori belajar humanistik ini dapat diartikan sebagai proses penemuan jati diri. Teori humanistik ini sangat tepat diperuntukkan dalam kegiatan belajar mengajar khususnya terhadap materi-materi yang mencakup membentuk kepribadian diri, perubahan sikap, tingkah laku, nurani hati dan analisis pada kejadian sosial. Wujud adanya keberhasilan ini seperti peserta didik merasakan bahagia dan antusias, memiliki kemauan belajar serta perubahan pola pikir, sikap dan tingkah laku dengan kehendak sendiri.

\section{Permainan Edukatif Bahasa}

Menurut Mujib, permainan adalah suatu kegiatan yang memiliki tujuan yakni mendapatkan satu kemampuan/keahlian tertentu, hal ini diperoleh dengan cara menyenangkan seseorang. Permainan bahasa merupakan salah satu metode atau cara efektif untuk membangkitkan minat siswa dalam hal belajar mengenai bahasa Arab. akan tetapi, permainan bahasa harus dipilih yang sesuai dengan media permainannya. Tujuan permainan bahasa adalah mendapatkan kesenangan serta melatih keahlian berbahasa (menyimak, berdialog, membaca, menulis, serta sastra) dan unsur- unsur bahasa (kosakata serta tata bahasa) (Mujib 2011, 26-32). Permainan edukatif bahasa bisa meliputi seluruh aspek keahlian berbahasa adalah keahlian menyimak, keahlian berdialog, keahlian membaca serta keahlian menulis.

\section{Pembelajaran Bahasa Arab di Sekolah Islam Terpadu}

Secara umum, Sekolah Islam Terpadu merupakan sekolah Islam yang diselenggarakan dengan memadukan secara integratif nilai serta ajaran Islam dalam bangunan kurikulum dengan pendekatan pendidikan yang efisien serta keterlibatan 
yang maksimal, dan kooperatif antara pendidik serta orang tua, dan masyarakat guna membina kepribadian serta kompetisi peserta didik.

Suyatno, berpendapat bahwa Sekolah Islam Terpadu merupakan pendatang baru pada lanskap pengembangan pendidikan di Indonesia (Suyatno 2015, 2). Amrulloh juga mengatakan bahwa Sekolah Islam Terpadu adalah lembaga pendidikan yang memiliki kemampuan untuk memadukan antara materi pengetahuan umum materi pengetahuan keagamaan yang berintegrasi. Setelah itu, output yang dihasilkan dari lembaga pendidikan ini lumayan memuaskan. Ada pula sebutan terpadu dimaksud selaku suatu sistem dengan pelaksanaan program full day school. Program ini menyelaraskan antara program pembelajaran umum dengan pembelajaran agama, antara pengembangan kemampuan intelektual (fikriyah), emosional (ruhiyah) serta raga (jasadiyah), dan antara sekolah, orang tua serta masyarakat selaku pihak yang mempunyai tugas serta tanggung jawab terhadap kegiatan belajar mengajar di sekolah (Amrulloh 2015, 13).

Dalam pengertiannya juga dijelaskan bahwa Sekolah Islam Terpadu menyelaraskan yakni antara pendidikan agama dan pendidikan umum. Aspek yang ditekankan pada Sekolah Islam Terpadu ini juga meliputi aspek kognitif, psikomotorik, dan afektif.

Mualimin berpendapat bahwasanya konsep Sekolah Islam Terpadu meliputi sebagai berikut:

\section{Kurikulum}

Pengembangan kurikulum pada pendidikan terpadu ini memiliki lima asas yang dapat dijadikan pedoman diantaranya adalah: pertama, asas jelas serta benar. Rincian rumusan dan tujuan pembelajaran wajib dimiliki oleh kurikulum pendidikan terpadu, hal ini tercantum pada RPP, Silabus, buku pegangan peserta didik, pendidik bahkan orang tua. Selain itu juga rincian tersebut dapat dipahami pada semua kalangan baik peserta didik, pendidik, orang tua dan masyarakat. Kedua, tertib serta berkelanjutan. Penyampaian pokok materi yang diajarkan oleh pendidik kepada peserta didik pada Kurikulum sekolah pendidikan wajib secara berurutan serta secara berkepanjangan. Maksudnya tiap pokok materi yang diajarkan di informasikan berjenjang serta berkepanjangan dalam sesuatu lapisan yang tertib, cocok 
dengan tingkatan umur serta kematangan psikologis, tidak terdapat modul yang terputus ataupun loncat-loncat pada urutan yang berantakan. Ketiga, efisien serta efektif. Kurikulum pada sekolah terpadu dirancang dengan memikirkan prinsip pas waktu serta pas guna, keempat, balance serta handal. Sekolah terpadu mencermati penyeimbang antar roh serta ide dan jasad. Program pengajaran dikemas biar menjangkau serta penuhi kebutuhan roh, ide, serta jasad tersebut, kelima, integratif serta merata. Upaya sekolah terpadu adalah mengintegrasikan terhadap seluruh aspek yang hendak mendukung untuk mencapai tujuan tertentu, serta membagikan bermacam keahlian yang lengkap serta merata untuk peserta didik.

2. Peserta didik

Aqidah yang baik harus dimiliki oleh peserta didik, ibadah dengan benar, mempunyai akhlak mulia, terampil serta cinta pada Al-Qur'an, cerdas akal budinya dan sehat jasmani dan rohani. Memiliki tindakan secara kreatif yakni mandiri, terampil dan bertanggung jawab. Memiliki sikap yang positif yakni jujur, toleran terhadap sesama, sopan santun, disiplin, rajin dan mencintai antar sesama.

3. Pendidik dan Tenaga Kependidikan

Pendidik dan Tenaga Kependidikan diharuskan untuk profesional. Artinya kemampuan atau kompetensi yang dimiliki harus sesuai dengan yang menjadi embannya, pemahaman terhadap agamanya dalam kehidupan sehari-hari. Mampu menjalin hubungan yang harmoni dengan peserta didik, orang tua bahkan anggota masyarakat.

4. Metode Pembelajaran

Metode yang digunakan dalam kegiatan belajar mengajar adalah bertukar pendapat, berdialog, diskusi, metode belajar kreatif, belajar dengan bantuan komputer yang terarah dan terkendali serta belajar dengan berbuat atau visitasi.

5. Evaluasi

Evaluasi disini mengacu pada semua aspek seperti afektif, kognitif dan psikomotorik dimana memiliki sifat berlangsung secara berkelanjutan serta edukatif. 
Bahasa Arab merupakan salah satu bahasa yang telah menjadi bahasa resmi dan telah diakui oleh internasional. Pada awalnya pembelajaran bahasa Arab ini hanya dipelajari di madrasah-madrasah namun, sejak saat ini bahasa Arab telah dilaksanakan dan diterapkan di sekolah-sekolah umum. Hingga pada akhirnya pembelajaran bahasa Arab telah tersebar di tiap sekolah termasuk tersebar di sekolah berbasis Islam Terpadu.

Wekke, berpendapat dalam penelitiannya bahwasannya kegiatan belajar mengajar bahasa Arab di Sekolah Islam Terpadu adalah memadukan dengan integrasi mata pelajaran bahasa Arab dengan mata pelajaran tertentu, terutama dalam materi yang berkaitan dengan al-Qur'an. Kegiatan belajar mengajar dengan al-Qur'an disajikan untuk penguatan keterampilan berbahasa (Wekke 2017, 191).

Tujuan dari adanya pembelajaran bahasa adalah untuk menguasai kompetensi berbahasa yang memadai. Karena dengan begitu, seseorang dapat menggunakan kemampuan tersebut dalam kebutuhan hidupnya sehari-hari. Contohnya bahasa digunakan sebagai sarana komunikasi untuk menyampaikan pesan atau mengungkapkan sesuatu pada orang lain dan juga mengajukan permintaan untuk mencapai apa yang diinginkannya (Suja'I 2010, 13).

Sama halnya dengan bahasa-bahasa lain di dunia, bahasa Arab mempunyai empat keterampilan berbahasa (مـارة اللغة) yang dapat disebut pula dengan فنون (seni-seni bahasa). Selain itu, salah satu aspek yang paling mendasar adalah bahasa sebagai alat komunikasi, hal ini dipahami dari adanya kata maharah tersebut. Kemampuan/keahlian merupakan hal yang paling utama dalam menggunakan suatu bahasa. Adapun empat kemampuan/keahlian yang disebut juga dengan empat maharah yaitu kemampuan mendengar (istima), kemampuan berbicara (kalam), kemampuan membaca (qira'ah) serta kemampuan menulis (kitabah) (Makruf 2009, 18).

Baroroh, dalam penelitiannya mengatakan bahwa model-model pengajaran bahasa Arab berbeda-beda dilihat dari lingkungan pendidikannya (Baroroh 2017, 57). Sekolah Islam Terpadu termasuk pengajaran di lingkungan formal, namun juga termasuk dalam lingkungan informal dan nonformal. Ini dikarenakan pengajaran bahasa Arabnya didukung oleh faktor-faktor yang menunjangnya seperti keluarga, masyarakat dan lain-lain. 


\section{HASIL DAN PEMBAHASAN}

Pendekatan humanistik dalam pembelajaran bahasa Arab mengedepankan tentang bagaimana sebuah pembelajaran bahasa dapat berlangsung secara mengasyikkan/menggembirakan dan juga tidak bersifat paksaan terhadap peserta didik. Dengan didukung konsep sistem pendidikan Sekolah Islam Terpadu yang telah dijelaskan tersebut, peserta didik bisa mengikuti kegiatan belajar mengajar bahasa Arab dengan patuh dan antusias. Pendidik berperan sebagai fasilitator untuk memotivasi peserta didik pada kegiatan belajar mengajar bahasa Arab. Gardner (1985) mengatakan bahwa motivasi pada pembelajaran bahasa merupakan langkah untuk seseorang berusaha dan bekerja dalam memahami suatu bahasa yang didasari atas keinginannya serta memiliki pengalaman tentang kepuasan yang dirasakan ketika melaksanakan suatu aktivitas belajar mengajar tersebut (Kamarul 2010, 58).

Berbagai metode pembelajaran yang bersifat sinektik (kreatif) juga mendukung proses kegiatan belajar mengajar bahasa Arab yakni melalui sebuah pendekatan humanistik yang dilaksanakan di Sekolah Islam Terpadu. Kemudian meliputi sarana dan prasarana seperti komputer dan lainnya membantu pengeksplorasian peserta didik dalam mengembangkan kebahasaannya.

Teori humanistik juga memberikan perhatian lebih kepada para peserta didik sebagai manusia bahwasanya untuk tidak merasa dirinya sebagai benda untuk merekam seperangkat pengetahuan tersebut. Teori ini menekankan pada aspek yang menjadi fokus dalam kegiatan belajar mengajar adalah peserta didik dan menjadikan peserta didik sebagai manusia artinya memanusiakan manusia (Muyassarah 2016, 427).

Terdapat tahapan-tahapan operasional tentang teori humanistik ini pada kegiatan belajar mengajar bahasa Arab diantaranya sebagai berikut:

1. Memberikan arahan dan penjelasan terhadap peserta didik untuk terus berlatih dan mendalami kemampuan bahasa Arab. hal ini dapat diterapkan dengan menggunakan bahasa Arab di setiap situasi dan kondisi.

2. Mengajak peserta didik untuk bermain peran (role playing) agar memberi respon terhadap situasi dan kondisi yang ada. 
3. Pendidik turut aktif dalam memberikan contoh pada peserta didik dalam hal yang nantinya dapat diikuti peserta didik.

Pembelajaran bahasa Arab membutuhkan metodologi yang sesuai atau cara pengajaran yang tepat (Asyrofi 2017, 20). Pembelajaran bahasa Arab ini tentunya membutuhkan penanganan yang optimal. Tidak jarang pula kita ketahui bahwasanya kegiatan pembelajaran bahasa asing misalnya bahasa Arab menjadi hal yang ditakuti bahkan tidak disukai oleh peserta didik. Namun dengan pendekatan humanistik melalui permainan bahasa, peserta didik dapat memiliki keantusiasan dalam mempelajarinya. Menurut Uliyah, memang permainan tidak selalu dibutuhkan pada saat kegiatan belajar mengajar bahasa Arab dan juga permainan itu sendiri tidak selamanya dapat meningkatkan kualitas proses dari pembelajaran bahasa Arab tersebut. Namun, dengan adanya permainan yang dimanfaatkan dan didesain dengan terampil dan juga bijaksana akan menjadi nilai tambah dalam meningkatkan minat serta semangat peserta didik pada proses pembelajaran. Setidaknya, permainan bahasa dapat menjadi alternatif bagi peserta didik dalam hal peningkatan keterampilan berbahasa dan belajar bahasa Arab mereka (Uliyah 2019, 36).

Pendekatan humanistik dengan permainan edukatif bahasa pada kegiatan belajar mengajar bahasa Arab dapat dilaksanakan dengan beberapa cara diantaranya:

1. Pendidik bertindak sebagai fasilitator untuk peserta didik yakni dengan cara memotivasi, memberikan penjelasan akan makna belajar, mendampingi peserta didik dan memberikan pengalaman belajar terbaik untuk peserta didik

2. Belajar kooperatif dengan permainan akan menimbulkan interaksi tatap muka semakin meningkat antara peserta didik juga dengan pendidik

3. Melatih tanggung jawab peserta didik

4. Peserta didik dapat mengaktualisasikan dirinya bahwa dengan menunjukkan dan membuktikan potensi dirinya kepada orang lain

5. Penempatan pendidik sebagai salah satu sumber belajar bagi peserta didik ini haruslah bersifat fleksibel. Artinya pendidik dapat berbaur dengan seluruh peserta didik 
6. Pemberian pujian pada peserta didik satu dengan peserta didik lainnya, hal ini dilakukan jika salah satu peserta didik dapat menyelesaikan permainan edukatif bahasa pada kegiatan belajar mengajar bahasa Arab dengan baik

Tujuan dari permainan bahasa ini adalah untuk mendapatkan kegembiraan serta melatih kemampuan berbahasa pula seperti menyimak, berbicara, membaca dan menulis dan juga unsur-unsur yang ada dalam bahasa Arab yaitu kosakata dan tata bahasa (Mujib 2011, 26-32).

Permainan edukatif bahasa mencakup seluruh aspek kemampuan berbahasa yaitu seperti kemampuan menyimak, kemampuan berbicara, kemampuan membaca dan kemampuan menulis. Berikut beberapa contoh permainan edukatif bahasa yang diperuntukkan dalam kegiatan belajar mengajar bahasa Arab melalui pendekatan humanistik:

\section{Permainan Kemampuan Mendengar (Istima')}

Permainan edukatif bahasa yang bisa digunakan oleh pendidik pada kegiatan belajar mengajar untuk kemampuan mendengar (istima') adalah sebagai berikut (Uliyah, 2019, 41-42):

\section{a. Bisik Kata}

Bisik kata atau juga dapat disebut sebagai kata berantai. Cara permainan ini yaitu dengan membisikkan kata atau kalimat kepada peserta didik lain atau pemain lain secara berurutan sampai selesai. Adapun kata atau kalimat untuk bisikkannya juga harus sesuai dengan pembelajaran bahasa Arab yang sedang berlangsung.

b. Kursi Bernomor

Kursi bernomor ini permainan untuk melatih kemampuan mendengar bagi peserta didik. Cara bermainnya pun cukup mudah yaitu misalnya ada 10 peserta didik dalam permainan yang duduk di masing-masing kursi yang telah diberi angka 1-10, kemudian salah satu dari peserta didik menyebutkan angka tertentu dari 1-10 misalnya saja angka 2 (isnan) dalam bahasa Arab. setelah itu, peserta didik atau pemain yang duduk di kursi nomor 2 menggunakan bahasa Arab juga menyebutkan angka dari 110, misalnya 7 (sab'ah) dan begitu seterusnya. Mengucapkan nomor harus tepat dan cepat karena jika peserta didik salah atau lama mengucapkan 
maka peserta didik tersebut harus pindah kursi sehingga peserta didik yang lain ikut berpindah juga.

\section{Permainan Kemampuan Berbicara (Kalam)}

Beberapa Permainan edukatif bahasa untuk keterampilan berbicara (kalam) adalah sebagai berikut (Mujib 2011, 126):

a. Pulpen Perkenalan

Permainan pulpen perkenalan ini digunakan untuk meningkatkan keterampilan berbicara. Cara bermainnya yaitu seluruh peserta didik agar membentuk lingkaran boleh dengan duduk atau berdiri. Kemudian salah satu peserta didik memberikan pulpen kepada salah satu pemain atau peserta didik. Pendidik akan menjelaskan sebelum permainan dimulai atau perputaran pulpen dimana ketika pulpen berhenti di salah satu peserta didik maka peserta didik harus memperkenalkan diri menggunakan bahasa Arab yaitu dengan menyebutkan nama, alamat, hobi, asal sekolah peserta didik. Setelah peserta didik tersebut menjawab, peserta didik memberikan pulpennya lagi kepada peserta didik yang lain. Bisa dilanjutkan dengan bertanya sesuatu hal. Atau biarkan peserta didik ini mengucapkan salam kemudian memulai perkenalan dengan peserta didik berikutnya.

b. Terka Aksi

Tujuan dari permainan terka aksi ini yaitu untuk melatih kecermatan, ketangkasan dan kreativitas pemain/peserta didik. Permainan ini membutuhkan alat yaitu kartu aksi. Adapun cara bermain terka aksi ini adalah pendidik membentuk masing-masing kelompok dari peserta didik kemudian memberikan kartu aksi pada tiap-tiap kelompok. Tiap-tiap kelompok tersebut harus menunjuk salah satu peserta didik lain dalam kelompok untuk dijadikan sebagai peraga untuk kartu aksi tersebut. Peserta didik tersebut melakukan peragaan dengan melihat dari kartu aksi tersebut dan untuk peserta didik lainnya bertugas untuk menebak apa yang telah diperagakan oleh rekannya.

\section{Permainan Keterampilan Membaca (Qira'ah)}

Berikut beberapa permainan edukatif bahasa untuk keterampilan membaca (qira'ah) (Mujib 2011, 85-87): 


\section{a. Tusuk Kata}

Tujuan dari permainan tusuk kata ini yaitu menambah kosa kata peserta didik dan juga peserta didik mampu mengelompokkan jenis kata bahasa Arab tersebut. Permainan tusuk kata ini sangat diperuntukkan untuk pengajaran pengelompokan. Contohnya pengelompokan mengenai ciri-ciri kalimat, aneka ragam kalimat, membedakan huruf jar, jazm, huruf athof dan lain-lain. Adapun alat-alat yang digunakan pada permainan tusuk kata ini yaitu lidi dan kertas. Untuk kertasnya sendiri dibentuk lingkaran dan ditulis dengan kosa kata bahasa Arab. Cara bermain permainan tusuk kata adalah peserta didik dibagi dalam beberapa kelompok, kemudian memberikan penjelasan kepada masing-masing kelompok tentang cara bermain tusuk kata. Kosa kata tersebut diacak dan masing-masing harus menemukan dan menyusun kata dengan kata yang sesuai dari kelompok tertentu. Peserta didik di sini mendiskusikan kata tersebut sesuai bagiannya. Di akhir, atau setelah permainan selesai, masing-masing kelompok mempresentasikan hasil dari diskusinya tersebut.

b. Strip story (potongan kertas)

Tujuan dari permainan ini adalah untuk memberikan bantuan kepada peserta didik agar dapat mampu mengurutkan kalimat secara sempurna dan juga tepat. Potongan kertas dari media strip story dapat digunakan untuk berbagai mata pelajaran contohnya seperti: muhadatsah, imla', muthola'ah, insya' dan mahfuzhah. Oleh karena itu, permainan ini dapat digunakan dalam kegiatan belajar mengajar kemampuan menulis (maharah kitabah).

4. Permainan Kemampuan Menulis (Kitabah)

Permainan edukatif bahasa untuk keterampilan menulis (kitabah) adalah sebagai berikut (Mujib 2011, 172-175):

a. Menulis Harakat

Permainan ini memiliki tujuan yaitu menguatkan serta meningkatkan pemahaman para peserta didik seperti pemahaman tentang harakat dan bunyi, menulis huruf yang tidak memiliki harakat, memberikan bantuan kepada peserta didik dalam mempelajari tulisan dan harakatnya, 
membantu peserta didik mengenali bunyi dan harakatnya dari sebuah huruf dan juga memiliki kemampuan untuk memberi harakat pada huruf. Cara bermainnya adalah peserta didik diberikan selembar kertas yang isinya adalah tulisan Arab belum memiliki harakat yang telah disediakan oleh pendidik. Kemudian peserta didik diminta untuk memberikan harakat teks tersebut sehingga bisa dibaca dan diterjemahkan. Teks tersebut tentunya harus sesuai dengan kebutuhan kondisi peserta didik seperti huruf Hijaiyah, kosakata (mufrodat) dan susunan kalimatnya.

b. Menggandeng Huruf

Tujuan dari permainan ini adalah peserta didik mampu untuk mengenal huruf Hijaiyah dan menyambungkannya. Adapun alat yang dibutuhkan diantaranya yakni pena, kertas dan buku iqra' digunakan untuk peraga. Cara bermainnya cukup mudah yaitu gambar dan potongan kalimat disediakan oleh pendidik sebagai kata kunci. Kemudian masing-masing peserta didik diberikan selembar kertas yang di dalamnya berisi gambar dan potongan kalimat. Peserta didik menyusun gambar dan potongan kalimat tersebut dengan benar dan tepat.

\section{KESIMPULAN DAN SARAN}

Pembelajaran bahasa Arab membutuhkan sebuah pendekatan seperti pendekatan humanistik yang memfokuskan pembelajaran kepada peserta didik. Khususnya di Sekolah Islam Terpadu, pendekatan humanistik dibutuhkan guna pembelajaran bahasa Arab yang menjadikan peserta didik cenderung lebih aktif untuk mengikuti kegiatan belajar mengajar. Dengan diselingi permainan edukatif bahasa dalam proses kegiatan belajar mengajar bahasa Arab akan menimbulkan minat dan juga kegemaran peserta didik. Dilihat dari sistem full day dari sekolah Islam Terpadu, pendekatan humanistik melalui permainan edukatif ini diperlukan guna mengurangi kejenuhan dan kebosanan bagi peserta didik yang dominannya belajar di dalam kelas. Selain itu, peserta didik juga dapat menemukan jati dirinya dan mengikuti proses kegiatan belajar mengajar bahasa Arab dengan baik. Dengan begitu, dapat menghasilkan output yang baik pula seperti mempunyai empat kemampuan berbahasa Arab yaitu kemampuan mendengar (istima'), kemampuan 
berbicara (kalam), kemampuan membaca (qira'ah) serta kemampuan menulis (kitabah) secara optimal.

Untuk para peneliti, penulis menyarankan agar penelitian mengenai pendekatan humanistik menggunakan permainan edukatif bahasa dalam kegiatan belajar mengajar bahasa Arab ini dapat berlanjut hingga ke penelitian lapangan sehingga dapat diketahui dan dibuktikan keefektifannya dari penggunaan pendekatan humanistik melalui permainan edukatif dalam kegiatan belajar mengajar bahasa Arab khususnya diterapkan di sekolah Islam Terpadu.

\section{REFERENSI}

Amrulloh, Amrulloh. 2017. "Sekolah Islam Terpadu: Sebuah Tinjauan Kritis." Tadrib: Jurnal Pendidikan Agama Islam, 1 no. 1: 1-15. http://jurnal.radenfatah.ac.id/index.php/Tadrib/article/view/1033.

Arifin, Ahmad. 2017. "Peranan Permainan Bahasa dalam Proses Kegiatan Belajar Mengajar Mata Pelajaran Bahasa Arab". An Nabighoh: Jurnal Pendidikan dan Pembelajaran Bahasa Arab, 19 no. 2: 302-318. https://doi.org/10.32332/annabighoh.v19i2.1005

Asyrofi, S. 2017. "Pengajaran Bahasa Arab di Madrasah dan Sekolah (Telaah Kritis dalam Perspektif Metodologis)." Al Mahāra: Jurnal Pendidikan Bahasa Arab, 3 no. 1: 20-30. https://doi.org/10.14421/almahara.2017.\%x

Aziz, Abd., dan Saihu. 2019. "Interpretasi Humanistik Kebahasaan: Upaya Kontekstualisasi Kaidah Bahasa Arab." Arabiyatuna: Jurnal Bahasa Arab, 3 no. 2: 299. https://doi.org/10.29240/jba.v3i2.1000

Baharuddin. 2007. Psikologi Pendidikan Refleksi Teoritis Terhadap Fenomena. Yogyakarta: Ar-Ruzz Media. 
Bakri, M. A. 2017. "Metode Langsung (Direct Method) dalam Pengajaran Bahasa Arab." Jurnal Pendidikan Bahasa Arab al-Maraji' ,1 no. 1: 1-12.

Baroroh, R. Umi. 2017. "Model-model Belajar Bahasa Arab di Indonesia Berdasarkan Lingkungan Berbahasa." Prosiding Konfererensi Nasional Bahasa Arab, 3 no. 3: 49-64.

Baroroh, R. Umi., dan Amrulloh, A. K. 2019. "Hypnoteaching Method in Arabic Learning." Al Bayan: Jurnal Jurusan Pendidikan Bahasa Arab, 11 no. 1: 133148. https://doi.org/10.24042/albayan.v11i1.3634

Bashori, Khoiruddin. 2002. 'Pendidikan Islam Terpadu, Mencari Model Komprehensif." El Tarbawi, 7 No. 5: 101-108.

Dierksmeier, Claus. 2016. "What is 'Humanistic' About Humanistic Management?" Humanistic Management Journal, 1: 9-32. https://doi.org/10.1007/s41463$\underline{016-0002-6}$

Hilmi. 2012. "Pendekatan Humanistik Dalam Belajar." Kompetens, 6: 1-11.

Husamah, dkk. 2018. Belajar dan Pembelajaran. Malang: UMM Press.

Kurnaengsih. 2015. "Konsep Sekolah Islam Terpadu." Risalah Pendidikan dan Studi Is/am, 1 no. 1: 78-84. https://doi.org/10.31943/jurnal risalah.v2i1.14

Mualimin, Mualimin. 2017. "Lembaga Pendidikan Islam Terpadu." Al-Tadzkiyyah: Jurnal Pendidikan Islam, 8 no. 1: 99-116. https://doi.org/10.24042/atjpi.v8i1.2099

Kamarul Shukri Mat Teh, dkk. 2011. "Hubungan Tahap Motivasi Dengan Strategi Pembelajaran Bahasa Arab Dalam Kalangan Pelajar Sekolah Menengah Agama 
Terengganu." Sains Humanika, 52 no. 1: 57-67. https://doi.org/10.11113/sh.v52n1.259

Muyassarah, Mufidatul Ilmi. 2016. "Teori Tentang Belajar dan Penerapannya dalam Pembelajaran Bahasa Arab." Prosiding Konferensi Nasional Bahasa Arab II: 245-256.

Latuconsina, Sarah. N. 2018. "Efektivitas Permainan Bahasa Arab dalam Meningkatkan Kemampuan Membaca Mahasiswa Program Studi Pendidikan Bahasa Arab". Arabi: Journal of Arabic Studies, 3 no. 2: 145-156. http://dx.doi.org/10.24865/ajas.v3i2.99

Ma'ruf, I. 2009. Strategi Pembelajaran bahasa Arab. Semarang: Need's Press

Maimunah. 2017. "Pembelajaran Bahasa Arab Berbasis Humanistik." Medina-Te, 12 no. 1: 77-86.

Maksudin. 2018. Pengembangan Kurikulum Bahasa Arab. Yogyakarta: FITK UIN Sunan Kalijaga.

Mujib, F., dan Nailur Rahmawati. 2011. Metode Permainan-Permainan Edukatif dalam Belajar Bahasa Arab. Yogyakarta: DIVA Press.

Nasrulloh, Muhammad Farid, Afif Kholisun Nasoih, Wisnu Siwi Satiti, and Septiana Khansa Afifa. 2020. "Mengatasi Problematika Pembelajaran Bahasa Arab Melalui Pelatihan Dan Permainan Bahasa Arab". Jumat Pendidikan: Jurnal Pengabdian Masyarakat 1 28-35. https://ejournal.unwaha.ac.id/index.php/abdimaspen/article/view/1040.

Prasetya, T. 2002. Filsafat Pendidikan untuk IAIN STAIN dan PTAIS. Bandung: Pustaka Setia.

Qodir, A. 2017. "Teori Belajar Humanistik Dalam Meningkatkan Prestasi Belajar Siswa." Jurnal Pedagogik, 4 no. 2: 188-202. 
Rachmahana, Ratna Syifa'a. 2008. "Psikologi Humanistik dan Aplikasinya dalam Pendidikan." El-Tarbawi, 1 no. 1: 99-114. https://doi.org/10.20885/tarbawi.vol1.iss1.art8

Sanusi, Uci. 2013. "Pembelajaran dengan Pendekatan Humanistik (Penelitian pada MTs Negeri Model Cigugur Kuningan." Ta'lim: Jurnal Pendidikan Agama Islam, 11

no. 2:

123-142.

http://jurnal.upi.edu/file/04 Pembelajaran dengan Pendekatan Humanistik Uci Sanusi.pdf

Sapri, Sapri. 2008. "Metode Pembelajaran Bahasa Arab: Antara Tradisional dan Modern." Insania: Jurnal Pemikiran Alternatif Pendidikan, 13 no. 03: 441-452. https://doi.org/10.24090/insania.v13i3.308

Solichin, Muchlis. 2018. "Teori Belajar Humanistik dan Aplikasinya dalam Pendidikan Agama Islam: Telaah Materi dan Metode Pembelajaran." Islamuna: Jurnal Studi Is/am, 5 no. 1. http://repository.iainmadura.ac.id/id/eprint/222

Supratinya. 1987. Terj. Mazhab Ketiga Psikologi Humanistik Abraham Maslow. Yogyakarta: Kanisius.

Suyatno, Suyatno. 2015. "Sekolah Islam Terpadu dalam Peta Sistem Pendidikan Nasional." Alqalam, 32 no. 2: 309. https://doi.org/10.32678/alqalam.v32i2.553

Tadjuddin, Andi Fajriwati. 2017. "Inovasi Pembelajaran Bahasa Arab." al-Maraji': Jurnal Pendidikan Bahasa Arab, 1 no. 1: 25-37. https://journal.unismuh.ac.id/index.php/al-maraji/article/view/2402

Teehankee, Benito. 2017. "Critical Realist Action Research and Humanistic Management Education." Academy of Management Proceedings, no. 1: 13285. https://doi.org/10.5465/ambpp.2017.13285abstract 
Uliyah, Asnul, dan Zakiyah Isnawati. 2019. "Metode Permainan Edukatif dalam Pembelajaran Bahasa Arab." Shaut Al-'arabiyah, 7 no. 1: 31-43. https://doi.org/10.24252/saa.v1i1.9375

Waddock, Sandra. 2016. "Developing Humanistic Leadership Education." Humanistic Management Journal, 1 no. 1: 57-73. https://doi.org/10.1007/s41463-016$\underline{0003-5}$

Wekke, Ismail Suardi. 2017. "Pengembangan Pembelajaran Keagamaan dan Bahasa Arab Di Madrasah Ibtidaiyah Minoritas Muslim." Tadrib, 3 no. 2: 187-196. https://doi.org/10.19109/Tadrib.v3i2.1793 